\title{
Primary biphasic synovial sarcoma of the lung:
} A case report

\author{
Hiroshi Hashimoto, Yuichi Ozeki, Koji Kameda, Hideyuki Shimazaki, \\ Kuniaki Nakanishi, Shinichi Taguchi
}

\begin{abstract}
Introduction: Primary synovial sarcoma of the lung is an extremely rare tumor, accounting for less than $0.5 \%$ of all lung tumors. The diagnosis is established only after sarcomalike primary lung malignancies and metastatic sarcoma have been excluded. Case Report: A 70-year-old female patient was admitted to our hospital because of a right lower lobe lung mass. Computed tomography-guided needle biopsy revealed the presence of spindle cell sarcoma. The patient underwent right lower lobectomy and combined resection of the pericardium. Histologically, the tumor displayed tubular proliferation of epithelial cells and fascicular proliferation of spindle cells. Immunohistochemically, both tumor cell types were positive for vimentin and bcl-2. Pleomorphic carcinoma or synovial sarcoma was suggested as a diagnosis. We found the presence of SYT-SSX fusion gene transcripts in RNA samples from frozen tissue from the tumor. The final diagnosis was primary pulmonary biphasic synovial sarcoma. Conclusion: We report an extremely rare case of primary
\end{abstract}

Hiroshi Hashimoto ${ }^{1}$, Yuichi Ozeki ${ }^{1}$, Koji Kameda ${ }^{1}$, Hideyuki Shimazaki ${ }^{2}$, Kuniaki Nakanishi ${ }^{2}$, Shinichi Taguchi ${ }^{1}$

Affiliations: ${ }^{1}$ Department of Thoracic Surgery, National Defense Medical College, 3-2, Namiki, Tokorozawa, Saitama, Japan; '2Department of Pathology and Laboratory Medicine, National Defense Medical College, 3-2, Namiki, Tokorozawa, Saitama, Japan.

Corresponding Author: Hiroshi Hashimoto, Department of Thoracic Surgery, National Defense Medical College, 3-2, Namiki, Tokorozawa, Saitama 359-8513, Japan; Email: hashimoh@ndmc.ac.jp

Received: 07 June 2018

Accepted: 28 June 2018

Published: 18 July 2018 pulmonary biphasic synovial sarcoma. Our findings indicate that molecular detection of SYT-SSX fusion gene transcripts is very helpful and may be necessary when synovial sarcoma is recognized at uncommon sites.

Keywords: Primary pulmonary synovial sarcoma, Synovial sarcoma, SYT-SSX fusion gene transcripts

\section{How to cite this article}

Hashimoto H, Ozeki Y, Kameda K, Shimazaki H, Nakanishi K, Taguchi S. Primary biphasic synovial sarcoma of the lung: A case report. Int $\mathrm{J}$ Case Rep Images 2018;9:100938Z01HH2018.

Article ID: 100938Z01HH2O18

$* * * * * * * *$

doi: 10.5348/100938Z01HH2018CR

\section{INTRODUCTION}

Synovial sarcoma is a morphologically well-defined neoplasm that most commonly occurs in soft tissues of the extremities [1]. This type of tumor accounts for $\sim 10 \%$ of all soft tissue sarcomas. Also this tumor has been described in numerous locations, including the head and neck, chest and abdominal wall. Primary synovial sarcoma of the lung is extremely rare and accounts for less than $0.5 \%$ of all lung tumor [2]. Here we report the case of a 70-year-old female patient who presented with a large right lower lobe lung mass lesion. The patient was subsequently diagnosed with primary biphasic synovial sarcoma of the lung and the tumor was completely resected surgically. 


\section{EDORIUM Journals}

Int J Case Rep Images 2018;9:100938Z01HH2018.

www.ijcasereportsandimages.com

\section{CASE REPORT}

A 70-year-old female patient presented with an incidentally found mass in the right lung. The mass was detected on a chest X-ray during a regular medical checkup (Figure 1). The patient was a non-smoker with no history of asbestos exposure. Physical and neurological examinations were unremarkable. The results of blood tests and standard biochemical tests were normal. Arterial blood gas analysis and tumor marker results were also normal.

A computed tomography (CT) scan of the chest revealed a $5 \mathrm{~cm}$ well-defined mass occupying the right lower lobe (Figure 2). CT-guided needle biopsy revealed the presence of spindle cell sarcoma. The tumor had rapidly enlarged in a short period after the needle biopsy. Since there was no evidence of distant metastasis, the patient underwent thoracotomy.

The tumor had directly invaded the pericardium and was adherent to the middle lobe (Figure 3). A right lower lobectomy with combined resection of the pericardium and radical lymph node dissection was performed. The postoperative course was uneventful and the patient was discharged on postoperative day 16.

Histopathological examination of the tumor revealed that it was a well-circumscribed, round tumor, $65 \times 45$ $\times 75 \mathrm{~mm}$ in size. The tumor had extensive macroscopic necrosis (Figure 4) and displayed tubular proliferation of epithelial cells and fascicular proliferation of spindle cells in a biphasic pattern (Figure 5). Although there was infiltration of the tumor into the pericardium, all surgical margins were tumor-free and the lymph nodes were not involved. Immunohistochemically, both epithelial cells and spindle cells were positive for vimentin and bcl-2, but negative for thyroid transcription factor-1, napsin A, CD34, CD117, demin, S-100, h-caldesmon, and anaplastic lymphoma kinase (Figure 6). We found SYT-SSX fusion gene transcripts in RNA samples from frozen tissue from the tumor. The final diagnosis was primary pulmonary biphasic synovial sarcoma.

\section{DISCUSSION}

Synovial sarcoma is a rare mesenchymal tumor, accounting for only $10 \%$ of all soft tissue tumors [3, 4]. It commonly occurs in soft tissue in the extremities in adolescents and young adults. However other sites including lung, mediastinum, heart, head and neck have been reported [5-7].

Primary synovial sarcoma of the lung is rare and accounts for less than $0.5 \%$ of all lung tumors [1]. It was described in 1995 by Zeren et al. as a distinctive primary sarcoma of the lung that nevertheless shared histological and immunohistochemical features with synovial sarcoma [8].

More than half of primary synovial sarcomas of the lung are centrally located and associated with obstructive

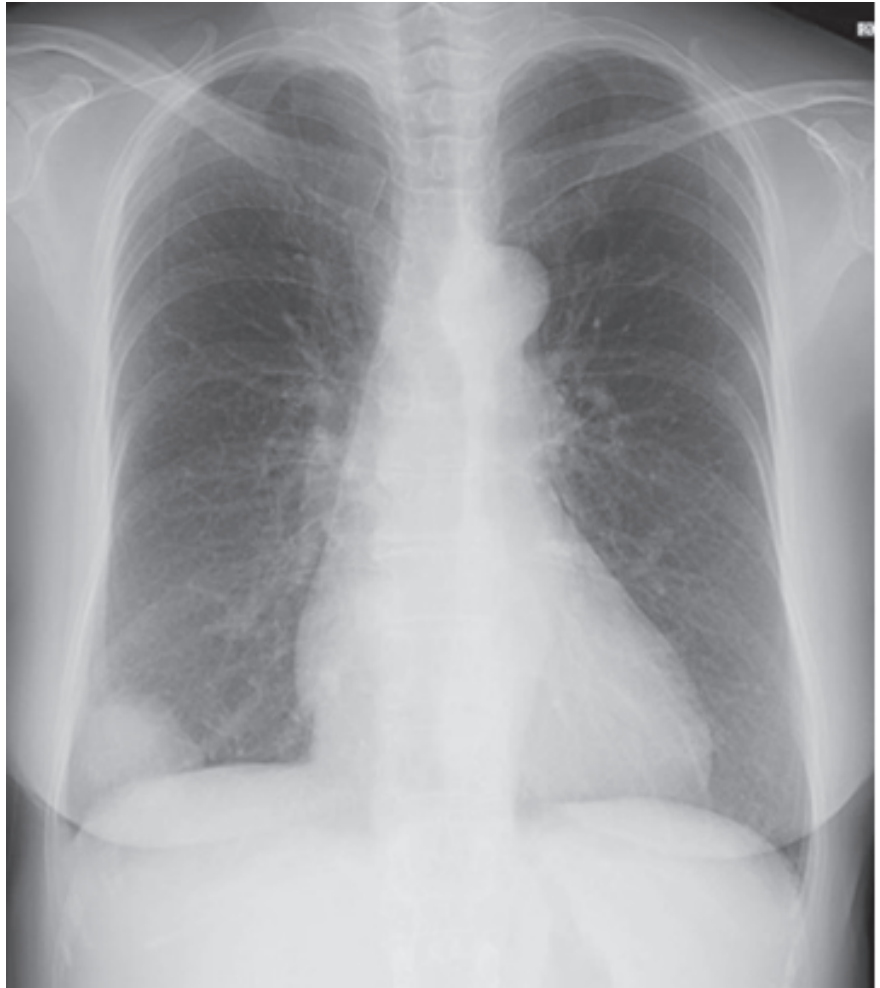

Figure 1: Chest roentegenogram. A homogeneous mass in the right lower lung field was revealed.

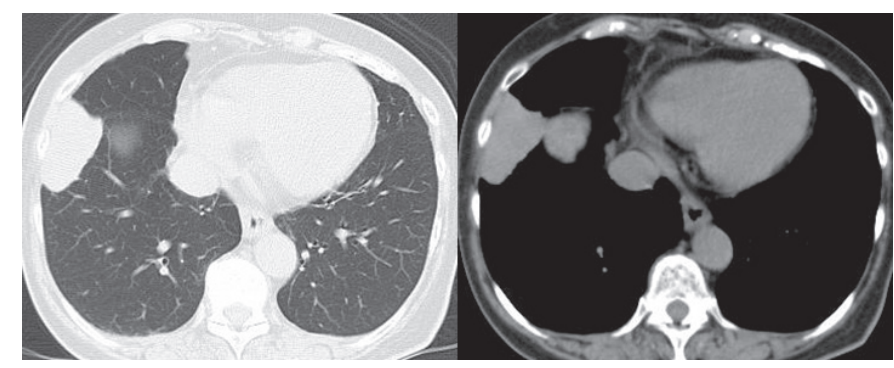

Figure 2: Chest computed tomography. A well-defined large mass occupying the right lower lobe was revealed.

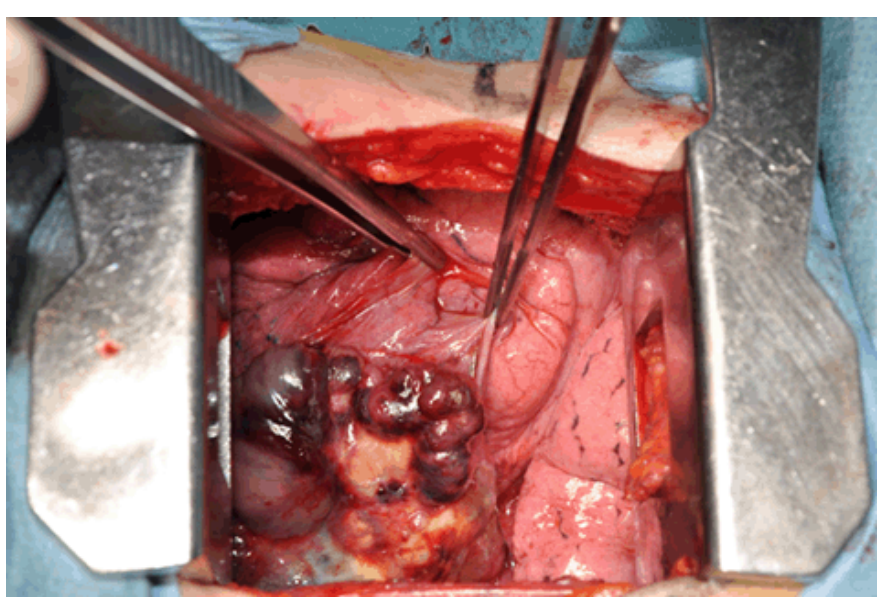

Figure 3: Findings at the operation. The tumor had directly invaded the pericardium. 


\section{EDORIUM Journals}

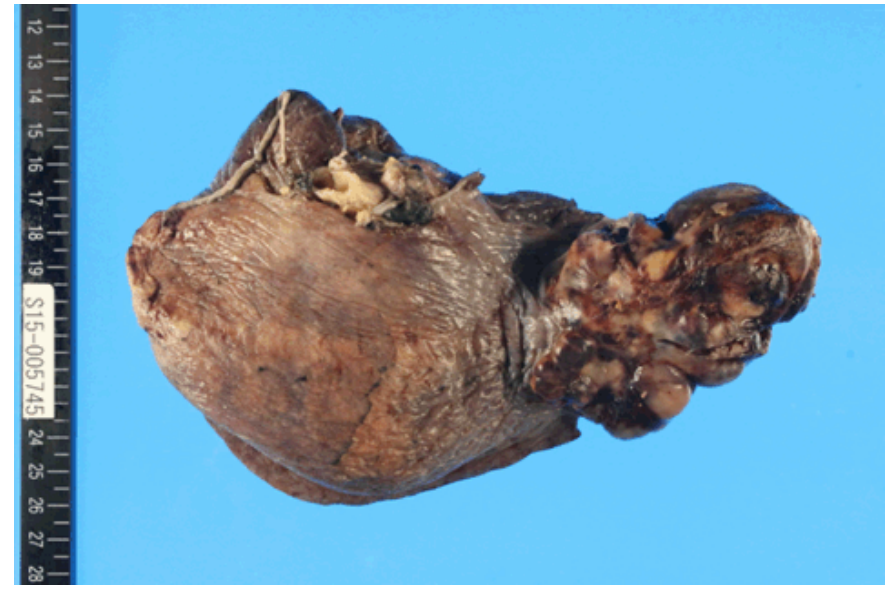

Figure 4: Macroscopic findings. Gross examination of the specimen revealed a well-circumscribed round tumor, $65 \times 45$ $\times 75 \mathrm{~mm}$ in size.

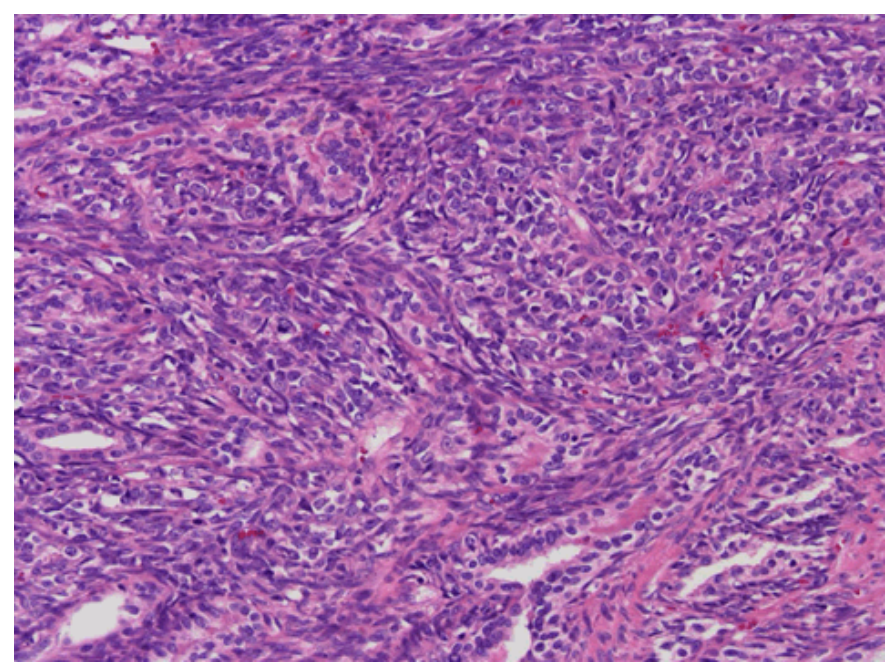

Figure 5: Microscoplic findings. The tumor displayed tubular proliferation of epithelial cells and fascicular proliferation of spindle cells with several mitotic features.

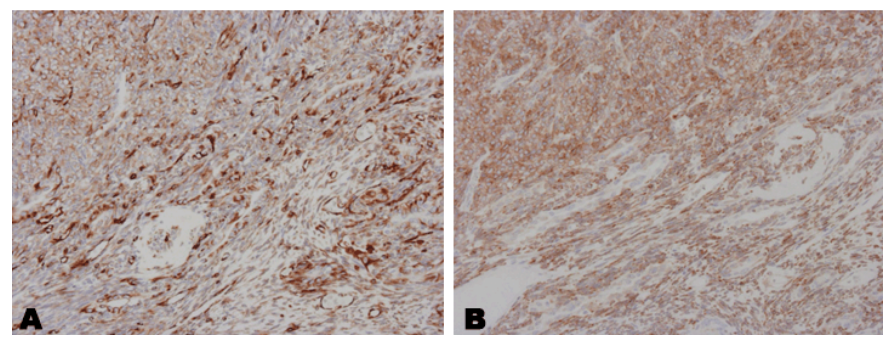

Figure 6: Immunohistochemical findings. Both epithelial cells and spindle cells were positive for vimentin (A) and bcl-2 (B).

pneumonia, atelectasis, and hemoptysis [9-13]. Peripheral tumors such as that described here are less common and usually asymptomatic. The tumor in the present case was also asymptomatic, although it had rapidly enlarged in a short period after CT-guided needle biopsy.
Primary synovial sarcomas of the lung fall into four subtypes: monophasic fibrous, monophasic epithelial, biphasic, and poorly differentiated. The monophasic subtype is the most common [14]. Although a diagnosis of biphasic synovial sarcoma is usually easy, focal well-formed papillary or adenomatoid areas may be interpreted as carcinomas or malignant mesotheliomas. In particular, pleomorphic carcinomas can present with spindle cell and adenocarcinoma components [12]. Carcinomas are more cytologically atypical and have greater pleomorphism than primary synovial sarcomas of the lung. Synovial sarcoma is characterized by a reciprocal chromosomal translocation $(\mathrm{X} ; 18)$ (p11.2; q11.2) that results from fusion of the SYT gene on chromosome 18 to one of two genes, (SSX1 and SSX2) on chromosome $\mathrm{X}$ [15-18]. Therefore, cytogenetic studies using reverse transcriptase- polymerase chain reaction are useful for difficult-to-diagnosis cases. In our case, the first tentative pathological diagnosis was pleomorphic carcinoma. After verifying the presence of SYT-SSX fusion gene transcripts, the final diagnosis was revised primary synovial sarcoma of the lung.

The therapy of choice in cases such as that presented here is surgical removal of the tumor with the aim of achieving negative resection margins. Complete surgical resection, and not the size or grade of the tumor is significantly associated with increased survival [19]. However, prognosis is poor in such cases. The effects of adjuvant chemoradiotherapy are unclear, as it has not been tested in randomized trials. Although complete removal of the tumor was successfully performed in the case presented here, the patient died due to the local recurrence of the tumor within one year after sugery.

\section{CONCLUSION}

Primary synovial sarcoma of the lung is an extremely rare and aggressive tumor with poor prognosis. It should be diagnosed using radiology, histology, immunohistochemistry, and molecular techniques. The most appropriate management for this condition is surgical excision with negative margins, although the prognosis is limited.

\section{REFERENCES}

1. Martini N, Hajdu SI, Beattie EJ Jr. Primary sarcoma of the lung. J Thorac Cardiovasc Surg 1971 Jan;61(1):338.

2. Travis WD, Travis LB, Devesa SS. Lung cancer. Cancer 1995 Jan 1;75(1 Suppl):191-202.

3. Cadman NL, Soule EH, Kelly PJ. Synovial sarcoma: An analysis of 134 tumors. Cancer 1965 May;18:61327.

4. Mankin HJ, Hornicek FJ. Diagnosis, classification, and management of soft tissue sarcomas. Cancer Control 2005 Jan-Feb;12(1):5-21. 


\section{EDORIUM Journals}

5. Weiss SW, Goldblum JR. Enzinger's and Weiss's Soft Tissue Tumors. 5ed. Philadelphia: Mosby Elsevier; 2008. p. 1161-82.

6. Roy P, Das A, Sarkar A, Dwari A, Datta S. A primary synovial sarcoma of lung. N Am J Med Sci 2012 May;4(5):241-3.

7. Chang CC, Chang PY. Primary pulmonary synovial sarcoma. J Cancer Res Pract 2018:5(1):24-6.

8. Zeren H, Moran CA, Suster S, Fishback NF, Koss MN. Primary pulmonary sarcomas with features of monophasic synovial sarcoma: A clinicopathological, immunohistochemical, and ultrastructural study of 25 cases. Hum Pathol 1995 May;26(5):474-80.

9. Essary LR, Vargas SO, Fletcher CD. Primary pleuropulmonary synovial sarcoma: Reappraisal of a recently described anatomic subset. Cancer 2002 Jan 15;94(2):459-69.

10. Bégueret H, Galateau-Salle F, Guillou L, et al. Primary intrathoracic synovial sarcoma: A clinicopathologic study of $40 \mathrm{t}(\mathrm{X} ; 18)$-positive cases from the French sarcoma group and the mesopath group. Am J Surg Pathol 2005 Mar;29(3):339-46.

11. Hartel PH, Fanburg-Smith JC, Frazier AA, et al. Primary pulmonary and mediastinal synovial sarcoma: A clinicopathologic study of 60 cases and comparison with five prior series. Mod Pathol 2007 Jul;20(7):760-9.

12. Mirzoyan M, Muslimani A, Setrakian S, Swedeh M, Daw HA. Primary pleuropulmonary synovial sarcoma. Clin Lung Cancer 2008 Sep;9(5):257-61.

13. Okamoto S, Hisaoka M, Daa T, Hatakeyama K, Iwamasa T, Hashimoto H. Primary pulmonary synovial sarcoma: A clinicopathologic, immunohistochemical, and molecular study of 11 cases. Hum Pathol 2004 Jul;35(7):850-6.

14. Enzinger FM, Weiss SW. Soft Tissue Tumors. 3ed. St Louis: Mosby; 1995. p. 757-86.

15. Fletcher CDM, Unni K, Mertens F. Pathology and Genetics of Tumours of Soft Tissue and Bone: World Health Organization Classification of Tumours. Lyon, France: IARC; 2002. p. 427.

16. Clark J, Rocques PJ, Crew AJ, et al. Identification of novel genes, SYT and SSX, involved in the $\mathrm{t}(\mathrm{X} ; 18)$ (p11.2;q11.2) translocation found in human synovial sarcoma. Nat Genet 1994 Aug;7(4):502-8.

17. Guillou L, Coindre J, Gallagher G, et al. Detection of the synovial sarcoma translocation $\mathrm{t}(\mathrm{X} ; 18)$ (SYT;SSX) in paraffin-embedded tissues using reverse transcriptase-polymerase chain reaction: A reliable and powerful diagnostic tool for pathologists. A molecular analysis of 221 mesenchymal tumors fixed in different fixatives. Hum Pathol 2001 Jan;32(1):105-12.

18. Park JS, Min BR, Park SH, Kwon KY, Keum DY, Choi WI. Primary pulmonary biphasic synovial sarcoma confirmed by molecular detection of a SYT-SSX2 fusion gene: Report of 1 case. Korean J Intern Med 2010 Sep;25(3):331-6.

19. Bacha EA, Wright CD, Grillo HC, et al. Srgical treatment of primary pulmonary sarcomas. Eur J Cardiothorac Surg 1999 Apr;15(4):456-6o.

\section{Author Contributions}

Hiroshi Hashimoto - Substantial contributions to conception and design, Acquisition of data, Analysis and interpretation of data, Drafting the article, Revising it critically for important intellectual content, Final approval of the version to be published

YuichiOzeki-Substantial contributions to conception and design, Acquisition of data, Analysis and interpretation of data, Drafting the article, Revising it critically for important intellectual content, Final approval of the version to be published

Koji Kameda - Substantial contributions to conception and design, Acquisition of data, Analysis and interpretation of data, Drafting the article, Revising it critically for important intellectual content, Final approval of the version to be published

Hideyuki Shimazaki - Substantial contributions to conception and design, Acquisition of data, Analysis and interpretation of data, Drafting the article, Revising it critically for important intellectual content, Final approval of the version to be published

Kuniaki Nakanishi - Substantial contributions to conception and design, Acquisition of data, Analysis and interpretation of data, Drafting the article, Revising it critically for important intellectual content, Final approval of the version to be published

Shinichi Taguchi - Substantial contributions to conception and design, Acquisition of data, Analysis and interpretation of data, Drafting the article, Revising it critically for important intellectual content, Final approval of the version to be published

\section{Guarantor of Submission}

The corresponding author is the guarantor of submission.

\section{Source of Support}

None

\section{Consent Statement}

Written informed consent was obtained from the patient for publication of this case report.

\section{Conflict of Interest}

Authors declare no conflict of interest.

\section{Copyright}

(C) 2018 Hiroshi Hashimoto et al. This article is distributed under the terms of Creative Commons Attribution License which permits unrestricted use, distribution and reproduction in any medium provided the original author(s) and original publisher are properly credited. Please see the copyright policy on the journal website for more information. 
Access full text article on other devices

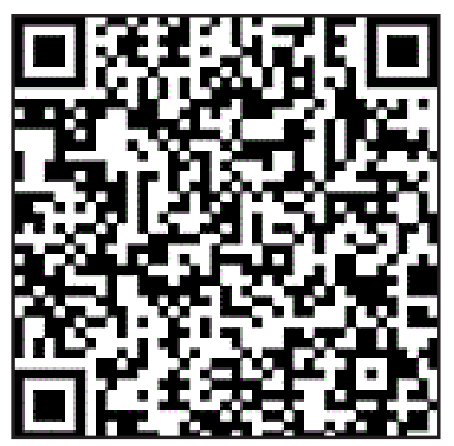

Access PDF of article on other devices

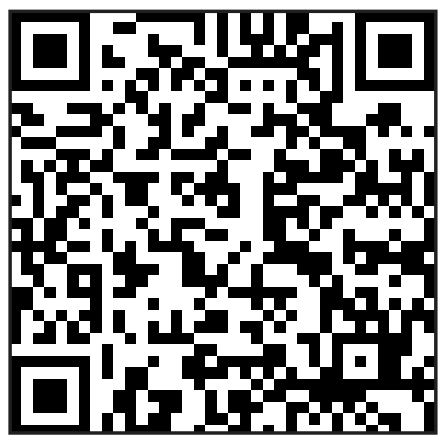

